\title{
Correction to: Trends in youth e-cigarette and cigarette use between 2013 and 2019: insights from repeat cross-sectional data from the COMPASS study
}

\author{
Adam G. Cole ${ }^{1,2}$ (D) Sarah Aleyan ${ }^{2,3} \cdot$ Kate Battista $^{2} \cdot$ Scott T. Leatherdale $^{2}$ \\ Published online: 10 November 2020 \\ (C) The Author(s) 2020
}

\section{Correction to: Canadian Journal of Public Health https://doi.org/10.17269/s41997-020-00389-0}

This article was updated to include additional funding information in the Acknowledgements.

Open Access This article is licensed under a Creative Commons Attribution 4.0 International License, which permits use, sharing, adaptation, distribution and reproduction in any medium or format, as long as you give appropriate credit to the original author(s) and the source, provide a link to the Creative Commons licence, and indicate if changes were made. The images or other third party material in this article are included in the article's Creative Commons licence, unless indicated otherwise in a credit line to the material. If material is not included in the article's Creative Commons licence and your intended use is not permitted by statutory regulation or exceeds the permitted use, you will need to obtain permission directly from the copyright holder. To view a copy of this licence, visit http://creativecommons.org/licenses/by/4.0/.

Publisher's note Springer Nature remains neutral with regard to jurisdictional claims in published maps and institutional affiliations.

The online version of the original article can be found at https://doi.org/10. 17269/s41997-020-00389-0

Adam G. Cole

adam.cole@uoit.ca

Sarah Aleyan

saleyan@uwaterloo.ca

Kate Battista

kbattista@uwaterloo.ca

Scott T. Leatherdale

sleatherdale@uwaterloo.ca

1 Faculty of Health Sciences, University of Ontario Institute of Technology, 2000 Simcoe Street North, Oshawa, Ontario L1G 0C5, Canada
2 School of Public Health and Health Systems, University of Waterloo, Waterloo, Ontario, Canada

3 Institute of Psychiatry, Psychology \& Neuroscience, King's College, London, London, UK 